\title{
Pengaruh Dukungan Sosial dan Proses Adaptasi dengan Status Kesehatan Mental Ibu Rumah Tangga Akibat Kebijakan Pembatasan Sosial Berskala Besar di Kota Jakarta Timur
}

\author{
Alvira Putri Calista*, Ayun Sriatmi*, Rani Tiyas Budiyanti* \\ *Fakultas Kesehatan Masyarakat, Universitas Diponegoro \\ Email:alvirapc2@gmail.com
}

\begin{abstract}
Imposing large-scale social restrictions has resulted in a transition of activity patterns in society. This change results in many activities that must be done at home, so that housewives try to adjust quickly to the situation. This demand raises mental health problems, which can also affect physical health, so that other people to provide support can be important value to housewives. This study aimed to analyze the effect of social support and adaptation processes on the mental health status of housewives, including levels of depression, levels of anxiety disorders, and levels of stress because of large-scale social restrictions. This research was a survey research with quantitative methods and using a cross-sectional design. Respondents of this study were 100 housewives who were taken using accidental sampling. Collecting data using a questionnaire and analyzed using the Rank Spearman test. The results showed a relationship between social support with the level of depression ( $p$ value $=0.014)$ and the level of anxiety disorders ( $p$-value $=0.030)$, as well as the adaptation process with the level of
\end{abstract}

depression $(p$-value $=0.002)$. There was a relationship between social support with the level of depression and the level of anxiety disorders in housewives, and the adaptation process with the level of depression in housewives. It is recommended that the East Jakarta City Government develop a program that involves selected communities to become mental health counselors. In addition, the puskesmas can make innovations in mental health efforts for families and optimize the role of mental health cadres.

Keywords: PSBB Policy, Mental health

\section{PENDAHULUAN}

Pandemik global COVID-19 melahirkan problematika baru bagi bangsa dan negara, khususnya mengenai bagaimana upaya untuk mencegah dan menghentikan penyebaran virus ini agar tidak semakin meluas. Penularan virus yang contagious ini telah menyebar hampir ke seluruh dunia dalam beberapa bulan termasuk Indonesia. Berdasarkan jumlah kasus per provinsi, urutan pertama jumlah kasus kondirmasi positif COVID-19 
terbanyak di Indonesia adalah Provinsi DKI Jakarta dengan Kota Jakarta Timur sebagai penyumbang angka terbesar kasus konfirmasi positif COVID-19 menurut data per 27 Mei $2020 .^{1}$

Berdasarkan data jumlah kasus konfirmasi positif COVID-19 yang memiliki kecenderungan mengalami peningkatan ditiap harinya, pemerintah Provinsi DKI Jakarta menempuh langkahlangkah strategis guna memutus mata rantai penyebaran COVID-19 dan melindungi penduduknya dengan pemberlakuan Pembatasan Sosial Berskala Besar. Dengan penetapan tersebut, sejumlah aktivitas warga akan dibatasi. ${ }^{2}$

Berdasarkan pelayanan swaperiksa masalah psikologis terkait pandemik COVID-19 secara daring melalui situs resmi www.pdskji.org yang dilakukan Perhimpunan Dokter Spesialis Kedokteran Jiwa Indonesia (PDSKJI), sampai dengan 23 April 2020, sebanyak 64,3\% (1.305 responden) dari 1.522 responden yang telah swaperiksa, memiliki masalah psikologis cemas atau depresi dan $76,1 \%$ di antaranya adalah perempuan. ${ }^{3}$

Selain itu, dalam sebuah suvei yang diinisiasi oleh Komisi Nasional Anti Kekerasan terhadap Perempuan pada Maret-April 2020 secara daring dengan mayoritas merupakan perempuan yang bekerja penuh waktu, menunjukkan bahwa perempuan semakin stres akibat pemberlakuan kebijakan PSBB. ${ }^{4}$

Dari hasil studi pendahuluan diketahui bahwa selama pemberlakuan Pembatasan Sosial Berskala Besar, ibu rumah tangga merasakan kesulitan dalam menjalani perubahan pola kegiatan sehari-hari. Selain itu, ibu rumah tangga juga mengalami beberapa gejala gangguan kesehatan mental diantaranya merasa kelelahan, lebih mudah marah dengan orang lain, dan sulit berkonsentrasi.

Perubahan pola rutinitas yang tak biasa dan kondisi yang mengharuskan banyak dirumah membuat banyak transisi pola aktivitas khususnya ibu rumah tangga. Perubahan pola aktivitas menyebabkan ibu rumah tangga berusaha menanggulangi berbagai kebutuhan, tekanan, rasa frustasi, dan konflik batin serta menyelaraskan tuntutan-tuntutan batin dengan tuntutantuntutan lingkungan dengan melibatkan respon-respon mental dan tingkah laku. Hadirnya orang lain yang dapat diandalkan untuk dimintai bantuan, dorongan, dan penerimaan kesulitan dalam berinteraksi dengan lingkungan sangat penting dalam perubahan situasi ini agar individu merasa diperhatikan, bernilai, dan dicintai. ${ }^{5}$

Munculnya gangguan kesehatan mental akan berpengaruh pada kondisi kesehatan ibu rumah tangga seperti penekanan fungsi sistem imun, penururnan status gizi, hingga gangguan pada sistem reproduksi. $^{6,7,8}$ Bila keadaan ini terus berlangsung, maka akan berpengaruh pada kesehatan Ibu rumah tangga itu sendiri maupun keluarga baik secara fisik, psikologis, dan sosial. Penelitian ini dilakukan untuk menganalisis status kesehatan mental ibu rumah tangga yang mencakup tingkat depresi, tingkat gangguan kecemasan, dan tingkat stres dan hubungannya dengan dukungan sosial serta proses adaptasi.

\section{METODE PENELITIAN}

Penelitian ini merupakan penelitian kuantitatif dengan desain cross sectional. Sampel penelitian ini sebanyak 100 orang yang ditentukan menggunakan teknik accidental sampling. Responden tersebut merupakan ibu rumah tangga yang berada di Kota Jakarta Timur saat pelaksanaan 
Pembatasan Sosial Berskala Besar. Penelitian ini dilakukan di Kota Jakarta Timur pada bulan September secara daring dalam bentuk Google Form yang disebarluaskan melalui media sosial dan telah mendapatkan persetujuan oleh Komisi Etik Penelitian Kesehatan FKM Undip dengan nomor 233/EA/KEPK-FKM/2020. Adapun variabel terikat dalam penelitian ini adalah status kesehatan mental yang meliputi tingkat depresi, tingkat gangguan kecemasan, dan tingkat stres yang diukur menggunakan kuesioner Depression Anxiety and Stress Scale versi 21 yang dikembangkan oleh Lovibond dan telah diterjemahkan kedalam Bahasa Indonesia. Variabel bebas terdiri dari dukungan sosial dan proses adaptasi yang diukur menggunakan kuesioner yang disusun oleh peneliti. Data yang dikumpulkan kemudian dianalisis secara bivariat menggunakan Rank Spearman.

Uji validitas dan reliabilitas untuk kuesioner DASS-21 menggunakan hasil uji validitas yang telah dilakukan oleh Kinanthi dan kawan-kawannya tahun 2020 yang berjudul Adaptasi Alat Ukur DASS-21 Versi Indonesia pada Populasi Mahasiswa diketahui bahwa kuesioner DASS 21 memiliki validitas dan reliabilitas yang baik. ${ }^{9}$ Sedangkan untuk uji validitas dan reliabilitas kuesioner dukungan sosial dan proses adaptasi, dilakukan kepada $30 \mathrm{ibu}$ rumah tangga yang berdomisili di luar Kota Jakarta Timur dan menghasilkan seluruh item dinyatakan valid dan reliabel. Analisis univariat dalam penelitian ini menggunakan distribusi frekuensi. Sedangkan analisis korelasi menggunakan Rank Spearman.

\section{HASIL DAN PEMBAHASAN}

Tabel 1. Distribusi Frekuensi Karakteristik Responden

\begin{tabular}{lcc}
\hline \multirow{2}{*}{ Karakteristik } & \multicolumn{2}{c}{ Responden } \\
\cline { 2 - 3 } Umur & Jumlah & Persentase \\
\hline 17-25 Tahun & 21 & 21,0 \\
\hline 26-35 Tahun & 24 & 24,0 \\
\hline 36-45 Tahun & 15 & 15,0 \\
\hline 46-55 Tahun & 22 & 22,0 \\
\hline 56-65 Tahun & 17 & 17,0 \\
\hline$>66$ Tahun & 1 & 1,0 \\
\hline Pendidikan Terakhir & & \\
\hline Tamat SMA & 30 & 30,0 \\
\hline Tamat Akademi / Perguruan Tinggi & 70 & 70,0 \\
\hline Pekerjaan & & \\
\hline Tidak Bekerja & 46 & 46,0 \\
\hline Karyawan Swasta & 28 & 28,0 \\
\hline PNS / ASN & 4 & 4,0 \\
\hline Wiraswasta & 13 & 13,0 \\
\hline Lainnya & 9 & 9,0 \\
\hline Penghasilan & & \\
\hline Tidak Berpenghasilan & 36 & 36,0 \\
\hline$<$ Rp 700.000 & 6 & 6,0 \\
\hline Rp 700.000 - Rp 1.300.000 & 6 & 6,0 \\
\hline Rp 1.300.000 - Rp 2.600.000 & 4 & 4,0 \\
\hline
\end{tabular}


Berdasarkan Tabel 1. menunjukkan bahwa persentase responden terbanyak berada pada rentang umur 26 - 35 tahun $(24,0 \%)$, memiliki tingkat pendidikan terakhir tamat akademi / perguruan tinggi $(70,0 \%)$, dengan jenis pekerjaan tidak bekerja (46,0\%), dan berpenghasilan diatas Rp 3.940.973 (38,0\%).

Tabel 2. Hasil Tabulasi Silang Antara Variabel Bebas dengan Status Kesehatan Mental Ibu Rumah Tangga di Kota Jakarta Timur

\begin{tabular}{|c|c|c|c|c|c|c|c|c|c|c|c|c|c|c|c|}
\hline \multirow{3}{*}{ Variabel } & \multicolumn{15}{|c|}{ Status Kesehatan Mental } \\
\hline & \multicolumn{5}{|c|}{ Depresi } & \multicolumn{5}{|c|}{ Gangguan Kecemasan } & \multicolumn{5}{|c|}{ Stres } \\
\hline & $\mathbf{N}$ & $\mathbf{R}$ & $\mathbf{S}$ & B & SB & $\mathbf{N}$ & $\mathbf{R}$ & $\mathbf{S}$ & B & SB & $\mathbf{N}$ & $\mathbf{R}$ & $\mathbf{S}$ & B & SB \\
\hline \multicolumn{16}{|c|}{ Dukungan Sosial } \\
\hline Kurang Baik & $66,7 \%$ & $12,7 \%$ & $12,7 \%$ & 6,3 , & $1,6 \%$ & $36,5 \%$ & $14,3 \%$ & 39,79 & \% 6,3c & c. $3,2 \%$ & $57,1 \%$ & $27,0 \%$ & $12,7 \%$ & $3,2 \%$ & $0,0 \%$ \\
\hline Baik & $64,9 \%$ & $24,3 \%$ & $10,8 \%$ & 0,0 , & $0,0 \%$ & $48,6 \%$ & $21,6 \%$ & 24,39 & \% $5,4 c$ & $0,0 \%$ & 62,29 & $21,6 \%$ & $13,5 \%$ & $2,7 \%$ & $0,0 \%$ \\
\hline \multicolumn{16}{|c|}{ Proses Adaptasi } \\
\hline Kurang Baik & $52,6 \%$ & $24,6 \%$ & $15,8 \%$ & 5,3 , & $1,8 \%$ & $40,4 \%$ & $17,5 \%$ & 33,39 & \% $8,8 c$ & $0,0 \%$ & 61,49 & $17,5 \%$ & $17,5 \%$ & $3,5 \%$ & $0,0 \%$ \\
\hline Baik & $83,7 \%$ & $7,0 \%$ & $7,0 \%$ & 2,3 , & $0,0 \%$ & $41,9 \%$ & $16,3 \%$ & 34,99 & \% 2,3c & $4,7 \%$ & $55,8 \%$ & $34,9 \%$ & $7,0 \%$ & $2,3 \%$ & $0,0 \%$ \\
\hline
\end{tabular}

Ket: N=Normal; R=Ringan; S=Sedang; B=Berat; $\mathrm{SB}=$ Sangat Berat

Berdasarkan Tabel 2. Diketahui bahwa kelompok dengan tingkat depresi ringan lebih besar persentasenya pada kelompok yang mempersepsikan dukungan sosial baik $(64,9 \%)$ dan yang mempersepsikan proses adaptasi kurang baik $(24,7 \%)$. Kelompok yang memiliki tingkat depresi sedang lebih besar persentasenya pada kelompok yang mempersepsikan dukungan sosial $(12,7 \%)$ dan proses adaptasi $(24,6)$ yang kurang baik. Pada kelompok yang tingkat keparahan depresinya berat persentasenya lebih besar pada kelompok yang mempersepsikan mempersepsikan dukungan sosial $(1,6 \%)$ dan proses adaptasi $(5,3)$ yang kurang baik. Lalu, kelompok dengan tingkat keparahan depresi sangat berat lebih besar persentasenya pada kelompok yang mempersepsikan dukungan sosial $(1,6 \%)$ dan proses adaptasi $(1,8 \%)$ yang kurang baik. Dapat disimpulkan bahwa kecenderungan terjadinya depresi pada kelompok yang mempersepsikan dukungan sosial dan proses adaptasi kurang baik.

Pada Tabel 2. diketahui kelompok dengan tingkat gangguan kecemasan ringan lebih besar persentasenya pada kelompok yang mempersepsikan dukungan sosial baik $(21,6 \%)$ dan proses adaptasi kurang baik $(17,5 \%)$. Lalu, kelompok yang memiliki tingkat gangguan kecemasan sedang persentasenya lebih besar pada kelompok yang mempersepsikan dukungan sosial kurang baik $(39,7 \%)$ dan proses adaptasi baik (34,9\%). Pada kelompok dengan tingkat gangguan kecemasan berat lebih besar persentasenya pada kelompok yang mempersepsikan dukungan sosial $(6,3 \%)$ dan proses adaptasi $(8,8 \%)$ yang kurang baik. Kelompok yang tingkat gangguan kecemasannya sangat berat lebih besar persentasenya pada kelompok yang mempersepsikan dukungan sosial kurang baik $(3,2 \%)$ dan proses adaptasi baik $(4,7 \%)$. Dapat disimpulkan bahwa adanya 
kecenderungan peluang mengalami gangguan kecemasan pada kelompok yang mempersepsikan dukungan sosial kurang baik dan proses adaptasi baik.

Ditinjau dari tingkatan keparahan stres, ditemukan bahwa kelompok yang memiliki tingkat keparahan stres ringan lebih besar persentasenya pada kelompok yang mempersepsikan dukungan sosial kurang baik $(27,0 \%)$ dan proses adaptasi baik $(34,9 \%)$. Kelompok dengan tingkat keparahan stres sedang persentasenya lebih besar pada kelompok yang mempersepsikan dukungan sosial baik $(13,5 \%)$ dan proses adaptasi kurang baik (17,5\%). Lalu, kelompok yang memiliki tingkat stres berat persentasenya lebih besar pada kelompok yang mempersepsikan dukungan sosial $(3,2 \%)$ dan proses adaptasi $(3,5 \%)$ yang kurang baik. Dapat disimpulkan bahwa adanya kecenderungan peluang mengalami stres pada kelompok yang mempersepsikan dukungan sosial dan proses adaptasi yang kurang baik.

Tabel 3. Hasil Analisis Bivariat Variabel Bebas dengan Status Kesehatan Mental Ibu Rumah Tangga di Kota Jakarta Timur

\begin{tabular}{lcccccc}
\hline \multirow{2}{*}{ Variabel } & \multicolumn{5}{c}{ Status Kesehatan Mental } \\
\cline { 2 - 7 } & \multicolumn{2}{c}{ Depresi } & Gangguan Kecemasan & \multicolumn{2}{c}{ Stress } \\
\cline { 2 - 6 } & $\boldsymbol{p}$-value & Keterangan & $\boldsymbol{p}$-value & Keterangan & p-value & Keterangan \\
\hline $\begin{array}{l}\text { Dukungan } \\
\text { Sosial }\end{array}$ & $0,014^{*}$ & $\begin{array}{l}\text { Ada } \\
\text { Hubungan }\end{array}$ & $0,030^{*}$ & $\begin{array}{l}\text { Ada } \\
\text { Hubungan }\end{array}$ & 0,241 & $\begin{array}{l}\text { Tidak Ada } \\
\text { Hubungan }\end{array}$ \\
\hline $\begin{array}{l}\text { Proses } \\
\text { Adaptasi }\end{array}$ & $0,002^{*}$ & $\begin{array}{l}\text { Tidak Ada } \\
\text { Hubungan }\end{array}$ & 0,204 & $\begin{array}{l}\text { Tidak Ada } \\
\text { Hubungan }\end{array}$ & 0,088 & $\begin{array}{l}\text { Tidak Ada } \\
\text { Hubungan }\end{array}$ \\
\hline
\end{tabular}

Ket: *=Uji Hubungan Signifikan

Berdasarkan Tabel 3. diketahui bahwa adanya hubungan antara dukungan sosial dengan tingkat depresi $(p$-value $=0,014)$ dan tingkat gangguan kecemasan ( $p$ value $=0,030$ ). Sedangkan antara dukungan sosial dengan tingkat stres tidak memiliki hubungan ( $p$-value $=0,241)$. Hal ini sejalan dengan penelitian yang dilakukan oleh Meta Amelia Widya Saputri yang menyatakan adanya hubungan antara dukungan sosial terhadap depresi. ${ }^{10}$ Hasil ini juga relevan dengan penelitian yang dilakukan yang dilakukan oleh Inggri Ocviani Ningsih yang menyatakan bahwa terdapat hubungan antara dukungan sosial dengan tingkat kecemasan. ${ }^{11}$

Dukungan sosial dapat menjadi sebuah aspek yang penting untuk mengadakan perubahan-perubahan yang diperlukan untuk menghadapi peran yang baru. ${ }^{12}$ Cohen dan Wills menemukan bukti bahwa dukungan sosial yang diberikan dalam menghadapi situasi yang menekan sangat berpengaruh pada meningkatnya fungsi adoptif individu. ${ }^{13}$

Namun menurut responden, tokoh masyarakat setempat tidak memberikan informasi dan motivasi, serta tidak selalu siap sedia memberikan bantuan bila ada kesulitan selama pelaksanaan PSBB. Memberikan informasi dan motivasi, serta selalu siap sedia memberikan bantuan merupakan beberapa bentuk aplikasi dari dua aspek dukungan sosial yaitu aspek dukungan informasi dan aspek dukungan instrumental. Dukungan informasi berupa 
saran, pengarahan, bimbingan, dan tanggapan disaat situasi mengancam. Hal ini dapat membantu dalam membuat keputusan untuk memecahkan masalah. Dukungan instrumental merupakan bentuk dukungan yang melibatkan bantuan langsung, misalnya bantuan finansial atau bantuan dalam mengerjakan sesuatu. Pemberian dukungan instrumental dapat menjadi sebuah keterampilan dalam mengatasi masalah dam dapat membantu individu menjadi mandiri. ${ }^{14}$

Pemberian dukungan secara efektif bergantung pada penilaian individu. Dukungan akan menjadi efektif apabila dukungan tersebut dinilai layak diterima oleh individu. Bagaimana individu menerima dukungan sosial, lebih merupakan suatu pengalaman pribadi yang melibatkan pendalaman masing-masing individu terhadap hubungan sosialnya dengan orang lain. ${ }^{10}$ Pelaksanaan kebijakan Pembatasan Sosial Berskala Besar ataupun kebijakan yang serupa di Indonesia khususnya Kota Jakarta Timur belum pernah diterapkan sebelumnya. Kurangnya pengalaman ini dapat memengaruhi responden dalam menerima dukungan sosial. $^{15}$

Namun, hasil penelitian ini mengenai hubungan antara dukungan sosial terhadap stres $(p$-value $=0,241)$, tidak sejalan dengan penelitian yang dilakukan oleh Ahmad Yanuar Fahmi Pamungkas pada tahun 2019 yang menunjukkan terdapat hubungan yang bermakna antara dukungan sosial dengan tingkat stres. ${ }^{16}$ Hal ini terjadi salah satunya dapat dipengaruhi oleh interaksi sosial.

Dukungan sosial diartikan sebagai suatu pola interaksi yang positif atau perilaku menolong yang diberikan pada individu yang membutuhkan dukungan. Blumer menyatakan bahwa manusia itu bertindak atas dasar segala sesuatu bermakna bagi dirinya, dan makna tersebut dapat dikembangkan melalui interaksi sosial dengan orang lain. Interaksi sosial merupakan salah satu dari dukungan sosial dimana dalam mencapai sesuatu seseorang juga membutuhkan dukungan dari orang lain yaitu motivasi dari lingkungan atau sosialnya. ${ }^{17}$

Berdasarkan Tabel 3. juga menunjukkan adanya hubungan antara proses adaptasi dengan tingkat depresi ( $p$ value $=0,014$ ). Hasil ini sependapat dengan penelitian sebelumnya terkait Mekanisme Koping dengan Tingkat Depresi pada Pasien Gagal Ginjal Kronik Pre Hemodealisa tahun 2019. ${ }^{18}$

Proses adaptasi secara psikologis atau dapat disebut dengan mekanisme koping adalah proses penyesuaian secara psikologi dengan memberikan mekanisme pertahanan diri dengan harapan dapat melindungi atau bertahan dari hal-hal yang tidak menyenangkan. Coping sendiri memiliki dua macam yaitu coping psikologis dan coping psikososial yang mana pada penelitian ini melihat coping psikologis untuk mengetahui bagaiaman persepsi atau penerimaan terhadap hal yang mengancam bagi dirinya. ${ }^{19}$

Pada penelitian ini responden menyatakan bahwa tidak mudah, menemukan kesulitan, serta tidak rileks dalam menjalani kehidupan sehari-hari selama pelaksanaan PSBB. Selain itu, responden merasa tidak senang dan nyaman dengan perubahan aktivitas sehari-hari akibat pelaksanaan PSBB. Tak hanya itu, akibat pelaksanaan PSBB ini responden juga merasa gelisah setiap melakukan aktivitas diluar rumah dan merasa cemas jika bertemu dengan orang lain.

Hal ini menunjukan adanya respon psikologis yang berbentuk emosi. Emosi merujuk pada suatu perasaan dan pikiran- 
pikiran yang khas, suatu keadaan biologis dan psikologis, serta serangkaian kecenderungan untuk bertindak. Pandangan mengenai emosi merujuk pada bagaimana emosi dapat memberikan pengaruh bagi individu untuk menyesuaikan diri dengan perubahan. $^{20}$ Keadaan ini merupakan keadaan psikologis yang mana merupakan salah satu faktor yang mempengaruhi penyesuaian diri menurut Schneiders. Keadaan mental yang sehat juga merupakan syarat tercapainya penyesuaian diri yang baik, sehingga apabila individu mengalami frustrasi maupun gangguan mental, maka penyesuaian diri individu tersebut akan terganggu. Namun, jika individu memiliki keadaan mental yang baik maka akan mendorong individu untuk memberikan respon yang selaras dengan dorongan internal maupun tuntutan lingkungan. ${ }^{18}$

Strategi coping bertujuan untuk mengatasi situasi dan tuntutan yang dirasa menekan, menantang, membebani dan melebihi sumberdaya yang dimiliki. Sumberdaya coping yang dimiliki seseorang akan mempengaruhi strategi coping yang akan dilakukan dalam menyelesaikan berbagai permasalahan. Jenis coping mana yang akan digunakan dan bagaimana dampaknya, sangat tergantung pada jenis masalah yang dihadapi. Keberhasilan atau kegagalan dari coping tersebut akan menentukan apakah reaksi terhadap masalah yang dihadapi akan menurun dan terpenuhinya berbagai tuntutan yang diharapkan. ${ }^{20}$

Pada penelitian ini, hasil uji bivariat antara proses adaptasi dengan gangguan kecemasan $(p$-value $=0,204)$ dan stres $(p$ value $=0,088$ ) tidak sependapat dengan penelitian yang dilakukan Adelina Sumoked yang mengemukakan bahwa adanya hubungan antara mekanisme koping terhadap kecemasan serta penelitian Emil
Huraini pada tahun 2014 menyatakan adanya hubungan antara mekanisme koping terhadap stres. ${ }^{21,22}$

Terdapat perbedaan yang jelas antara individu satu dengan yang lain, dimana hal ini dapat terlihat dari perbedaan karakteristik kepribadian yang dimiliki oleh masing-masing individu. Hal ini menjadi salah satu faktor yang dapat memengaruhi tidak adanya hubungan proses adaptasi dengan gangguan kecemasan maupun stres. Kepribadian merupakan gabungan kualitas, kebiasaan dan reaksi yang terbentuk atas dasar kesadaran yang dikenali sebagai suatu hal yang baik atau tidak sesuai dengan kebiasaannya yang kemudian direspon secara positif atau tidak oleh seseorang yang melakukan kontak dengan individu. Reaksi yang terbentuk dari penggabungan kualitas dan kebiasaan inilah memunculkan respon dari pihak yang melakukan kontak dengan individu dan respon tersebut menjadi sebuah penilaian. ${ }^{23}$

Adanya perbedaan kepribadian antara satu dengan yang lain karena sebagai proses penyesuaian diri pada kondisi tertentu tidak dapat dimanipulasi karena kepribadian memperlihatkan suatu kekhususan antar individu. Menurut Hurlock, kepribadian manusia dibedakan menjadi dua yaitu kepribadian Tipe A dan kepribadian Tipe B. Secara umum perbedaan antar individu kepribadian Tipe A dan kepribadian Tipe B terletak pada pola pikir kedua tipe.

Perbedaan pola pikir antar individu ini menghasilkan berbagai upaya dalam mengorientasikan suatu masalah sehingga usaha yang digunakan untuk menyelesaikan masalah antar individu juga berbeda. Akibatnya antar individu memiliki perbedaan dalam mengambil keputusan. Perbedaan antar individu terlihat dari sifat dan perilaku yang menjadikan adanya 
perbedaan pada pemilihan stretegi coping saat menghadapi masalah. ${ }^{24}$

\section{KESIMPULAN}

Berdasarkan hasil penelitian dan pembahasan yang telah dilakukan mengenai didapatkan kesimpulan bahwa Mayoritas responden berumur antara 26 sampai 35 tahun, memiliki tingkat pendidikan terakhir tamat akademi / perguruan tinggi, dengan jenis pekerjaan tidak bekerja, dan berpenghasilan diatas Rp 3.940.973.

Hasil uji statistic menunjukkan adanya hubungan antara dukungan sosial terhadap tingkat depresi dan tingkat gangguan kecemasan. Selain itu, terdapat hubungan antara proses adaptasi dengan tingkat depresi.

Disarankan pihak Pemerintah Kota Jakarta Timur dapat mengembangkan program yang melibatkan masyarakat yang sesuai kriteria untuk menjadi konselor yang melakukan upaya promotive dan preventif kesehatan jiwa. Selain itu, pihak Puskesmas dapat melakukan inovasi pada upaya kesehatan jiwa dengan memanfaatkan sosial media untuk melakukan psikoedukasi mengenai kesehatan jiwa pada keluarga dan mengoptimalisasikan peran kader kesehatan jiwa di masyarakat yang telah dilakukan pelatihan terlebih dahulu oleh professional kesehatan mental dengan proaktif dalam melakukan upaya promotive dan preventif kesehatan jiwa.

\section{UCAPAN TERIMAKASIH}

Penulis mengucapkan terima kasih kepada Dinas Kesehatan Provinsi DKI Jakarta dan Suku Dinas Kesehatan Kota Jakarta Timur atas izin yang diberikan untuk melaksankan penelitian. Selain itu, penulis turut berterima kasih kepada seluruh responden yang telah bersedia berpartisipasi dalam penelitian ini.

\section{DAFTAR PUSTAKA}

1. Gugus Tugas Percepatan Penanganan COVID-19. Data Covid-19 [Internet]. 2020 [updated 2020 May 26; cited 2020 May 28]. Available from: https://covid19.go.id/peta-sebaran

2. Gubernur Provinsi Daerah Khusus Ibukota Jakarta. Peraturan Gubernur Provinsi Daerah Khusus Ibukota Jakarta Nomor 33 Tahun 2020 tentang Pelaksanaan Pembatasan Sosial Berskala Besar dalam Penanganan Corona Virus Disease 2019 (COVID19) di Provinsi Daerah Khusus Ibukota Jakarta; 2020

3. Perhimpunan Dokter Spesialis Kedokteran Jiwa Indonesia (PDSKJI). Swaperiksa Masalah Psikologi [Internet]. 2020. [cited 2 Juni 2020]. Available from: http://pdskji.org/home

4. Komisi Nasional Anti Kekerasan terhadap Perempuan. Siaran Pers Hasil Kajian Komnas Perempuan tentang Perubahan Dinamika Rumah Tangga dalam Masa Pandemi Covid-19. 2020 [cited 10 Juni 2020]. Available from: https://www.komnasperempuan.go.id/r ead-news-siaran-pers-hasil-kajiankomnas-perempuan-tentangperubahan-dinamika-rumah-tanggadalam-masa-pandemi-covid-19-3-juni2020

5. Handono OT, Bashori K. Hubungan Antara Penyesuaian Diri Dan Dukungan Sosial Terhadap Stres Lingkungan Pada Santri Baru. EMPATHY Jurnal Fakultas Psikologi 2013, 1(2):79-89.

6. Bilqis AM, Yaunin $\mathrm{Y}$, Darwin E. Hubungan Tingkat Ansietas dengan Infeksi Saluran Pernafasan Akut pada Mahasiswa Kedokteran Universitas 
Andalas Angkatan 2015-2016. Jurnal Kesehatan Andalas 2018, 7(3):320324.

7. American Psychological Association. Stress Effects on the Body. 2018 [cited 10 Juni 2020]. Available from: https://www.apa.org/helpcenter/stress/

8. Amalia, Rizki. Hubungan Stres Dengan Kelancaran ASI pada Ibu Menyusui Pasca Persalinan Di RSI A.Yani Surabaya. Jurnal Ilmiah Kesehatan 2016, 9(3):12-16.

9. Kinanthi, Melok, dkk. Adaptasi Alat Ukur DASS-21 Versi Indonesia pada Populasi Mahasiswa. 2020

10. Amelia M, Saputri W, Indrawati ES. Hubungan Antara Dukungan Sosial dengan Depresi Pada Lanjut Usia yang Tinggal di Panti Wreda Wening Wardoyo Jawa Tengah. Jurnal Psikologi Undip 2011, 9(1):65-72

11. Ningsih, Inggri O. Hubungan Antara Dukungan Sosial Terhadap Tingkat Kecemasan pada Ibu Hamil di Pontianak Barat. Jurnal Mahasiswa PSPD FK Universitas Tanjungpura 2015. 3(1)

12. Setyaningsih S, Mu'in M. Dukungan Sosial dan Tingkat Kecemasan pada Kelompok Pekerja PNS yang Menghadapi Masa Pensiun. Jurnal Keperawatan Komunitas 2013, 1(2):116-20.

13. Gutomo T, Ikawati. Pengaruh Dukungan Sosial terhadap Kondisi Kecemasan dalam Menghadapi Pensiun (Post Power Syndrome). Jurnal PKS 2014, 13(1):83-98.

14. Marni A, Yuniawati R. Hubungan Antara Dukungan Sosial dengan Penerimaan Diri pada Lansia di Panti Wredha Budhi Dharma Yogyakarta. EMPATHY Jurnal Fakultas Psikologi 2015, 3(1):1-7.
15. Wiranti, Sriatmi A, Kusumastuti W. Determinan Kepatuhan Masyarakat Kota Depok terhadap Kebijakan Pembatasan Sosial Berskala Besar dalam Pencegahan COVID-19 2020. Jurnal Kebijakan Kesehatan Indonesia 2020. 9(3):117-24.

16. Fahmi A. Hubungan Dukungan Sosial dengan Tingkat Stres pada Warga Binaan Pemasyarakatan Perempuan di Lembaga Pemasyarakatan. Holistic Nursing and Health Science 2019, 2(2):42-47.

17. Handono OT, Bashori K. Hubungan Antara Penyesuaian Diri dan Dukungan Sosial Terhadap Stres Lingkungan pada Santri Baru. EMPATHY Jurnal Fakultas Psikologi 2013, 1(2):79-89.

18. Yulianto A, Wahyudi Y, Marlinda. Mekanisme Koping dengan Tingkat Depresi pada Pasien Gagal Ginjal Kronik Pre Hemodealisa. Jurnal Wacana Kesehatan 2019, 4(2):436-44.

19. Choirudin M. Penyesuaian Diri: Sebagai Upaya Mencapai Kesejahteraan Jiwa. Hisbah: Jurnal Bimbingan Konseling dan Dakwah Islam 2015, 12(1):1-20.

20. Maryam S. Strategi Coping : Teori Dan Sumberdayanya. Jurnal Konseling Andi Matappa 2017, 1(2):101-7.

21. Sumoked A. Hubungan Mekanisme Koping Dengan Kecemasan Pada Mahasiswa Semester Iii Program Studi Ilmu Keperawatan Fakultas Kedokteran Yang Akan Mengikuti Praktek Klinik Keperawatan. Jurnal Keperawatan 2019, 7(1):1-7.

22. Mesuri RP, Huriani E, Sumarsih G. Hubungan Mekanisme Koping dengan Tingkat Stres Pada Pasien Fraktur. Ners Jurnal Keperawatan. 2014;10(1):66-74. 
23. Fitriani A. Pendekatan "empat $p$ " dalam Kegiatan Pendidikan dan Pembelajaran. Cendekia: Jurnal Kependidikan dan Kemasyarakatan 2011, 9(1):56-64.

24. Cahyono B. Analisis Keterampilan Berfikir Kritis dalam Memecahkan Masalah Ditinjau Perbedaan Gender. Aksioma: Jurnal Matematika dan Pendidikan Matematika 2017, 8(1):5064. 